\title{
Vascular Plant Checklists from Oklahoma
}

Michael W. Palmer

Department of Botany

Oklahoma State University

Stillwater OK 74078

email: mike.palmer@okstate.edu

A bibliography of 85 references involving Oklahoma flora is provided, 52 of which provide a vascular plant species list from an unambiguous area. I list geographic, topographic, and taxonomic summary data for $\mathbf{5 9}$ floras (some references provide multiple lists). The species-area relationship for Oklahoma (with a $\mathrm{z}$ value of 0.15 ) is similar to that of North America as a whole. In the face of imminent climate change, the pace of floristic research in Oklahoma needs to accelerate.

\section{INTRODUCTION}

Vascular plant checklists are proving valuable as raw material for broad-scale analyses of biodiversity (Qian and Ricklefs 1999; Chiarucci and Bonini 2005). But they also prove a more basic (and arguable more essential) function: to guide practicing botanists in the field. For either purpose, it is useful to have access to bibliographic data to find such floras.

The Floras of North America project (not to be confused with the Flora of North America Project, Flora of North America Editorial Committee 1993) is an attempt to catalogue and analyze vascular floras within North America, north of Mexico. The purpose of this paper is to present a bibliography of floristic checklists within Oklahoma, and to provide basic geographic and taxonomic data for comparative purposes.

\section{METHODS}

I used standard library techniques as well as informal inquiries to gather bibliographic information on floras from throughtout North America. I then extracted geographic data (with help from maps and geographic databases) and summarized the number of taxa in the species lists. In some cases geographic data are approximate. Details about the methodology are given in Fridley et al. (2006), Palmer (1995, 2005, 2007), Qian (in press), and Withers et al. (1998) as well as

http://botany.okstate.edu/floras/index.html

\section{RESULTS AND DISCUSSION}

I found 85 references including floristic lists, or with titles suggesting the presence of such lists (Appendix 1). Of these, I was able to gather complete data (minimum and maximum latitude and longitude, minimum and maximum elevation, and the number of families, genera, species, total taxa, and $\%$ alien species) for 51 references (Appendix 2).

The vascular plant species-area relationship for Oklahoma is remarkably similar to that of North America as a whole (Figure). The slope of the line, known in biogeography as the z coefficient, is 0.150 , and is similar to that of many continental species-area relationships (Rosenzweig 1995). The fact that there is much scatter around the species-area relationship implies that there may be interesting variation in biodiversity that can be explained by environmental or biogeographic factors. 
While the list of Oklahoma floras may seem impressive, a number of other states (led by California, Virginia, Iowa, Louisiana, Illinois, Texas, Arizona, Ohio, New York, and Wyoming) have surpassed us in numbers of floristic publications. Current work by Oklahoma botanists is helping to rectify the situation, with the work of Bruce Hoagland and his colleagues being most notable. Nevertheless, there are ample opportunities for new teams of botanists, including dedicated amateurs, to become involved with basic floristic research. Indeed, with extreme climate change predicted for the region (Seager et al. 2007), it may not be too long before we lose many of our vascular plant species. Thus, the time to document their existence is now.

\section{REFERENCES CITED}

Chiarucci, A. and I. Bonini. 2005. Quantitative floristics as a tool for the assessment of plant diversity in Tuscan forests. Forest Ecology and Management 212: 160-170.

Committee, F.o.N.A.E. 1993. Flora of North America. Oxford University Press, New York.

Fridley, J.D., H. Qian, P.S. White, and M.W. Palmer. 2006. Plant species invasions along the latitudinal gradient in the United States: comment. Ecology 87: 3209-3213

Palmer, M.W. 1995. How should one count species? Natural Areas Journal 15: 124-135.

Palmer, M.W. 2005. Temporal trends of exotic species richness in North
American floras: an overview. Écoscience 12: 386-390.

Palmer, M.W. 2007. Species-area curves and the geometry of nature. Pages 15-31 In: D. Storch, P.A. Marquet, and J.H. Brown, editors. Scaling Biodiversity. Cambridge University Press, Cambridge.

Qian, H., J.D. Fridley, and M.W. Palmer. A latitudinal gradient in species-are relationships for vascular plants of North America. American Naturalist. In press.

Qian, H. and R.E. Ricklefs. 1999. A comparison of the taxonomic richness of vascular plants in China and the United States. American Naturalist 154: 160-181.

Rosenzweig, M.L. 1995. Species diversity in space and time. Cambridge University Press, Cambridge.

Seager, R., M. Ting, I. Held, Y. Kushnir, J. Lu, G. Vecchi, H-P. Huang, N. Harnik, A. Leetmaa, N-C. Lau, C. Li, J. Velez, and N. Naik. 2007. Model Projections of an Imminent Transition to a More Arid Climate in Southwestern North America. Science 316: 1181-1184.

Tyrl, R.J., S.C. Barber, P. Buck, W.J. Elisens, P. Folley, L.K. Magrath, C.L. Murray, B.A. Smith, C.E.S. Taylor, and R.A. Thompson. 2007. Keys and Descriptions of the Vascular Plants of Oklahoma. Flora Oklahoma Inc., Noble.

Withers, M.A., M.W. Palmer, G.L. Wade, P.S. White, and P.R. Neal. 1998. Changing patterns in the number of species in North American floras. In T.D. Sisk, editor. Perspectives on the Land Use History of North America: A Context for Understanding our Changing Environment. USGS, Biological Resources Division, BSR/BDR-19980003; p 23-32. 


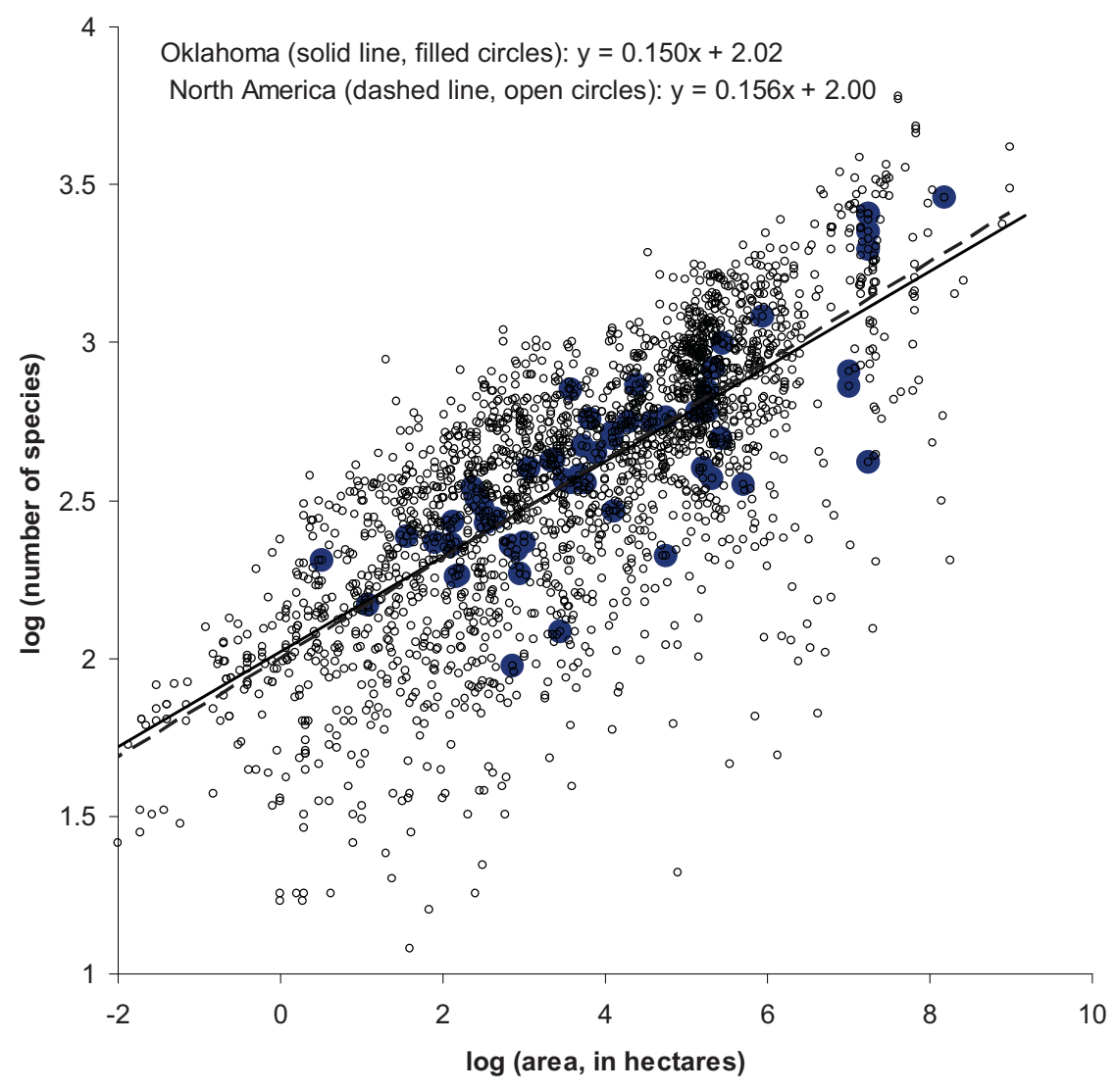

Figure Species-area relationship for 59 Oklahoma floras (data from Appendix 2) in comparison with 2283 lists from throughout North America. 
Appendix 1 Vascular plant checklists written within Oklahoma. Although not conventionally included in bibliographies, first names are included, when available, to allow more ready identification of the scholars involved. The citation ends with a bracketed reference number associated with the Floras of North America project and the author reference in Appendix 2. Some citations are not floras, but are included here because their titles resemble those of floras and including them in this list avoids accidental rediscovery. Keywords follow the citations:

COMPLETE = all taxonomic and geographic data have been gathered; DATA DUPLICATE $=$ the same data are available in another source listed elsewhere; NO AREA = the geographical area is impossible to determine based on available information; NO DATA YET = the reference has either not yet been seen, or it has not been evaluated; NOT A FLORA = despite the name, the document is not a flora; OTHER STATES = data include regions outside Oklahoma; TAXA EXCLUDED = data were not gathered because some taxa (e.g. ferns, graminoids) were intentionally excluded.

Baalman, R.J. (1964): Plants collected at Salt Plains National Wildlife Refuge during 1963 and 1964. Salt Plains National Wildlife Refuge, Jet. COMPLETE [3248]

Baalman, R.J. (1965): Vegetation of the Salt Plains Wildlife Refuge, Jet, Oklahoma. Ph.D. Dissertation, University of Oklahoma, Norman. 129 p. NO DATA YET [21328]

Baldock, L.O. (1938): Flora of Kiowa County, Oklahoma. M.S. Thesis, Oklahoma Agricultural and Mechanical College, Stillwater. 71 p. COMPLETE [89]

Barber, S.C. (1989): Floristic components of the Gypsum Hills and Redbed Plains of southwestern Oklahoma. Southwest. Nat. 24, 431-437. DATA DUPLICATE [91]

Barber, S.C. (1975): A floristic study of the vascular plants of the Gypsum Hills and Redbed Plains area of Southwestern Oklahoma. M.S. Thesis, Oklahoma State University, Stillwater. 84 p. COMPLETE [90]

Barkley, E.A. (1933): A preliminary survey of the vascular plants of Pottawatomie County, Oklahoma. Proc. Okla. Acad. Sci., 45-46. NOT A FLORA [1547]

Barkley, E.A.D. (1933): A preliminary list of the vascular plants of Pottawatomie
County, Oklahoma. M.S. Thesis, University of Oklahoma, Norman. 27 p. COMPLETE [92]

Bogue, E.E. (1900): Annotated catalogue of the ferns and flowering plants of Oklahoma. Okla. Exp. Sta. Bull. 45, 348. COMPLETE [1228]

Buck, P. (1977): Vascular plants of the Wichita Mountains Wildlife Refuge. Unpublished Report. COMPLETE [674]

Buckallew, R.; Caddell, G.M. (2001): A floristic study of plant communities at the Uco Selman Living Laboratory in the Gypsum Hills of northwestern Oklahoma. Proc. Okla. Acad. Sci. 81, 81. DATA DUPLICATE [20922]

Buckallew, R.R.; Caddell, G.M. (2003): Vascular flora of the University of Central Oklahoma Selman Living Laboratory, Woodward County, Oklahoma. Proc. Okla. Acad. Sci. 83, 31-45. COMPLETE [21316]

Buckallew, R.R. (2002): A floristic survey and description of vascular plant communities at the Selman Living Laboratory, Woodward County, Oklahoma. MS Thesis, University of Central Oklahoma. 122 p. COMPLETE [21259] 
Bull, R.Z. (1932): Vascular plants of Greer County, Oklahoma. M.S. Thesis, University of Oklahoma, Norman. 29 p. COMPLETE [94]

Clark, L.C.G. (1997): Floristic and biosystematic investigations in plant taxonomy. Ph.D. Dissertation, Oklahoma State University. 248 p. COMPLETE [20002]

Crandall, R.M. (2003): Vegetation of the Pushmataha Wildlife Management Area, Pushmataha County, Oklahoma. MS Thesis, Oklahoma State University, Stillwater. 114 p. COMPLETE [21287]

Dale, E.E. Jr (1946): A preliminary survey of the flora of the Arbuckle Mountains. M.S. Thesis, University of Oklahoma, Norman. DATA DUPLICATE [2208]

Dale, E.E., Jr (1956): A preliminary survey of the flora of the Arbuckle Mountains. Texas J. Sci. 8, 41-73. COMPLETE [96]

Dale, E.E., Jr (1959): The grasslands of Platt National Park, Oklahoma. Southwest. Nat. 4, 45-60. NO AREA [2210]

Dwyer, D.D. (1958): An Annotated plant list of Adams' Ranch, Osage County, Oklahoma. M.S. Thesis, Fort Hays Kansas State College, Hays. NO DATA YET [97]

Eskew, CT (1938): The flowering plants of the Wichita Mountains Wildlife Refuge. Amer. Midl. Nat. 20, 695-703. TAXA EXCLUDED [556]

Eskew, CT (1937): The flowering plants of Wichita National Forest. M.S. Thesis, University of Oklahoma, Norman. TAXA EXCLUDED [1116]

Folley, P (1994): Checklist of plants found in Cleveland County. 15100 Etowah Rd., Noble OK 73068, (405)872-8361. COMPLETE [4852]
Folley, P. (2003): Additions to Black Mesa Flora Study. Oklahoma Native Plant Record 3, 19-22. COMPLETE [21363]

Gage, H.A. (1908): A preliminary list of the plants of the Arbuckle Mountains. B.A. Thesis, University of Oklahoma, Norman. 48 p. COMPLETE [98]

Great Plains Flora Association (1977): Atlas of the Flora of the Great Plains. Univ. of Iowa Press, Ames, Iowa. 600 pages. NO DATA YET, OTHER STATES [804]

Great Plains Flora Association (1986): Flora of the Great Plains. University Press of Kansas, Lawrence. 1392 pages. COMPLETE, OTHER STATES [536]

Hayes, C.R. (2003): The vascular flora of the Sally Bull Hollow Tract of the Ozark Plateau National Wildlife Refuge, Adair County, Oklahoma. MS Thesis, Oklahoma State University. 33 p. COMPLETE [21266]

Hoagland, B.W.; Buthod, A.K. (2003): Vascular flora of the Keystone Wildlife Management Area, Creek, Pawnee, and Osage Counties, Oklahoma. Oklahoma Native Plant Record 3, 23-37. COMPLETE [21364]

Hoagland, B.W.; Buthod, A.K. (2004): Vascular flora of Hugo Lake Wildlife Management Area, Choctaw County, Oklahoma. Southeastern Naturalist 3, 701-714. COMPLETE [21407]

Hoagland, BW; Buthod, AK (2005): Vascular flora of a gypsum dominated site in Major County, Oklahoma. Proc. Okla. Acad. Sci. 85, 1-8. COMPLETE [21706]

Hoagland, B.W.; Buthod, A.K.; Elisens, W. (2004): Vascular flora of Washita Battlefield National Historic Site, 
Roger Mills County, Oklahoma. Sida 21, 1187-1197. COMPLETE [21491]

Hoagland, B.W.; Crawford, P.H.C.; Crawford, P.T.; Johnson, F. (2004): Vascular flora of Hackberry Flat, Frederick Lake, and Suttle Creek, Tillman County, Oklahoma. Sida 21, 429-445. COMPLETE [21360]

Hoagland, B.W.; Johnson, F. (2004): The vascular flora of Red Slough and Grassy Slough Wildlife Management Areas, Gulf Coastal Plain, McCurtain County, Oklahoma. Castanea 69, 284296. ; COMPLETE [21479]

Hoagland, B.W.; Johnson, F. (2004): Vascular flora of Love Valley Wildlife Management Area, Love County, Oklahoma. Proc. Okla. Acad. Sci. 84, 9-18. COMPLETE [21707]

Hoagland, B.W.; Johnson, F.L. (2001): Vascular flora of the Chickasaw National Recreation Area, Murray County, Oklahoma. Castanea 66, 383400. COMPLETE [20021]

Hoagland, B.W.; Wallick, K. (2003): Vascular flora of Oolagah Wildlife Management Area in Nowata County, Oklahoma. Proc. Okla. Acad. Sci. 83, 47-62. COMPLETE [21315]

Hoagland, B.W. (2001): Floristic list for Oklahoma County. Oklahoma Native Plant Record 1, 25-38. COMPLETE [20010]

Holzinger, J.M. (1892): List of plants collected by C. S. Sheldon and M. A. Carleton in the Indian Territory in 1891. Contrib. U.S. Nat. Herb. 1, 189-219. NOT A FLORA [1305]

Jeffs, R.E. (1931): A Key to the Ferns and Seed Plants of Oklahoma. University Mimeograph Pub. Norman. TAXA EXCLUDED [2229]

Jeffs, R.E.; Little, Elbert L., Jr (1930): A preliminary list of the ferns and seed plants of Oklahoma. Univ. Okla. Biol. Surv. Publ. 2, 39-101. COMPLETE [1117]

Johnson, F.L.; Estes, J.R.; Lomolino, M.V.; Roedel, M.D.; Proctor, M.D.; McCarty, N.A.; Leimgruber, P.; DeMarais, B.D.; Fuller, M.M.; Holloway, A.K.; Schnell, G.D. (1996): Biological survey of Vance Air Force Base. (Final Report to Department of the Air Force, Headquarters 338 Training Support Group (ATC) 338 CONS/LGCU, 550 D Street East STE 08, Randolph Air Force Base, Texas 78150-4434. Contract No. M6700491D0018) Oklahoma Biological Survey, Norman. 102 pages. COMPLETE [21371]

Johnson, F.L.; Folley, Patricia A.; McCarty, N.A.; Benesh, D.L. (1998): Floral inventory of Pontotoc Ridge Preserve, Oklahoma. (Report to the Nature Conservancy) Oklahoma Native Plant Society and Oklahoma Biological Survey, Norman. 24 pages. COMPLETE [21372]

Johnson, F.L.; Proctor, MD; McCarty, NA; Benesh, DL (1996): Biological Survey of Altus AFB, Oklahoma. Part 1. Floral Inventory. Oklahoma Biological Survey, Norman. COMPLETE [21373]

Johnson, F.L.; Proctor, MD; Young, EA; McCarty, NA; Vezey, EL; Schnell, GD (1994): Floral Inventory of Camp Gruber, Oklahoma. (Final Report to U.S. Army Construction Engineering Research Laboratories, Champaign, Illinois. Contract \#DACA 88-90-D0038, Delivery Order No. 0001) Oklahoma Biological Survey, University of Oklahoma, Norman. 49 pages. COMPLETE [21370] 
Johnson, F.L.; Thompson, R.A.; Rudman, R.; Estes, J.R.; Schnell, G.D.; Harris, K.D. (1990): Floral inventory of Fort Sill, Oklahoma. Oklahoma Biological Survey, Norman, Oklahoma. 114 pages. (Report to U.S. Army Construction Engineering Research Laboratory, Champaign, IL) COMPLETE [671]

Lahman, M.S. (1931): Observations of the Flora of Delaware County, Oklahoma. Proc. Okla. Acad. Sci. 11, 32-34. COMPLETE, NOT A FLORA [2050]

Little, E.L. Jr (1938): Flora of Muskogee County, Oklahoma. Amer. Midl. Nat. 19, 369-389. COMPLETE [99]

Little, E.L. Jr (1929): A botanical survey of Muskogee County, Oklahoma. Ph.D. Dissertation, University of Chicago. 203 p. COMPLETE [1882]

McCoy, D.A. (1958): Vascular plants of Pontotoc County, Oklahoma. Amer. Midl. Nat. 59, 371-396. COMPLETE [101]

McDonald, C.B. (1974): A floristic study of Washington County, Oklahoma. Proc. Okla. Acad. Sci. 56, 53-54. NOT A FLORA [103]

McDonald, C.B. (1974): A floristic study of the native or naturalized vegetation of Washington County, Oklahoma. M.S. Thesis, Oklahoma State University, Stillwater. 93 p. TAXA EXCLUDED [102]

McGregor, R.L.; Barker, W.T.; Barkley, T.M.; Wilson, JS (1975): Checklist of the Plants of the Great Plains. University of Kansas Herbarium, Lawrence, Kansas. NO DATA YET, OTHER STATES [70]

McPherson, J.K. (2003): Black Mesa Flora Study. Oklahoma Native Plant Record 3, 8-18. COMPLETE [21362]
Means, F.H. (1969): Vascular plants of southeastern Oklahoma from the Sans Bois to the Kiamichi Mountains. Ph.D. Thesis, Oklahoma State University, Stillwater. 179 p. COMPLETE [104]

Mericle, L.W. (1941): The spermatophytes of Custer County, Oklahoma. MS Thesis, University of Oklahoma, Norman. TAXA EXCLUDED [21357]

Myers, W.S. (1929): A preliminary report on the flora of the Wichita Mountains. M.S. Thesis, University Oklahoma, Norman. 121 p. NO DATA YET [105]

Ozga, C.M. (1992): Atlas to the flora of Woods County. Northwestern Oklahoma State University, Alva. 206 pages. NO DATA YET [20844]

Palmer, M.W. (1993): Vascular plant diversity in Oklahoma. Oklahoma State University Center for Water Research, Stillwater. 30 pages. COMPLETE [1975]

Riddell, J.L.: (1835): A Synopsis of the Flora of the Western States. E. Deming, Cincinnati, OH. 116 pages. NO DATA YET, OTHER STATES [1663]

Roe, S.A. (1992): The vegetation of a tract of ancient cross timbers in Osage County, Oklahoma. MS Thesis, Oklahoma State University. 86 p. COMPLETE [20001]

Rogers, C.M. (1953): The vegetation of the Mesa de Maya Region of Colorado, New Mexico and Oklahoma. Lloydia 16, 257-290. COMPLETE [2051]

Rydberg, P.A. (1932): Flora of the Prairies and Plains of Central North America. New York Botanical Garden, Bronx, NY. 969 pages. NO AREA, OTHER STATES [651] 
Schnell, G.D.; Johnson, F.L.; Gentry, J.L. Jr (1979): Flora and fauna of Oklahoma abandoned mine lands. Oklahoma Biological Survey, Norman. 132 pages. NOT A FLORA [106]

Shannon, K.A. (1997): A Floristic Survey of the Nature Conservancy's Preserve in Johnston County, Oklahoma. MS Thesis, Oklahoma State University. 38 p. COMPLETE [20003]

Shannon, K.A. (2003): Floristic survey of The Nature Conservancy's Pennington Creek preserve in Johnston County, Oklahoma 1997. Oklahoma Native Plant Record 3, 38-50. DATA DUPLICATE [21365]

Sherwood, R.T.B.; Risser, P.G. (1980): Annotated checklist of the vascular plants of Little Sahara State Park, Oklahoma. Southwest. Nat. 25, 323338. COMPLETE [107]

Smith, B.A.; Tyrl, R.J.; Masters, R.E. (1997): Floristic Inventory of the McCurtain County Wilderness Area, Oklahoma. Proc. Okla. Acad. Sci. 77, 99-102. COMPLETE [20005]

Smith, B.A. (1997): Floristic Investigations of the Flora of Oklahoma. Ph.D. Dissertation, Oklahoma State University. 171 p. DATA DUPLICATE [20004]

Stemen, T.R.; Myers, WS (1937): Oklahoma Flora. Harlow Publishing Corporation, Oklahoma City. 706 pages. TAXA EXCLUDED [829]

Stevens, G.W. (1916): The flora of Oklahoma. M.S. Thesis, Harvard University, Cambridge, Mass. TAXA EXCLUDED [2211]

Taylor, C.E.S. (1961): Ecology and taxonomy of Water Canyon, Canadian County, Oklahoma. M.S. Thesis, University of Oklahoma, Norman. 43 p. NO DATA YET [2054]
Taylor, C.E.S.; Magrath, L.K.; Folley, P.; Buck, P.; Carpenter, S. (1996): Oklahoma vascular plants: additions and distributional comments. Proc. Okla. Acad. Sci. 76, 31-34. NO DATA YET [20870]

Taylor, R.J.; Taylor, C.E.S. (1991): An Annotated List of the Fern, Fern Allies, Gymnosperms and Flowering Plants of Oklahoma. 2nd ed. Biology Department Herbarium, Southeastern Oklahoma State University, Durant, OK. 117 pages. COMPLETE [1964]

Taylor, R.J.; Taylor, C.E.S. (1994): An annotated list of the ferns, fern allies, gymnosperms and flowering plants of Oklahoma. 3rd ed. Southeastern Oklahoma State University, Durant, Oklahoma. 133 pages. COMPLETE [20006]

Taylor, R.J.; Taylor, C.E.S. (Eds.) (1989): An annotated list of the ferns, fern allies, gymnosperms, and flowering plants of Oklahoma. 1st ed. Southeastern Oklahoma State University, Durant, Oklahoma. 110 pages. NO DATA YET [4303]

The Nature Conservancy (1993): Plants of the Tallgrass Prairie Preserve, Osage County. Tallgrass Prairie Preserve, Pawhuska Office. COMPLETE [4095]

Tyrl, R.J. (1980): Identification and mapping of the extant flora at the Deer Creek archaeological site (34Ka 3, Kaw Lake, Oklahoma). (Final Report.) Environmental Resources Branch, U.S. Army Corps of Engineers, Tulsa, Oklahoma. 31 pages. COMPLETE [2056]

University of Tulsa, Faculty of Natural Sciences (1977): A biological inventory of the Fort Gibson Lake area. U.S. Dept. of the Army, Corps 
of Engineers, Tulsa Dist. NO AREA [2212]

Van Vleet, A.H. (1902): Plants of Oklahoma. Dept. of Geol. and Nat. Hist. Second biennial report. 1901-1902:138-160. COMPLETE [1232]

Wallis, C.S. (1959): Vascular plants of the Oklahoma Ozarks. Ph.D. Thesis, Oklahoma State University, Stillwater. NO DATA YET [108]

Waterfall, U.T. (1952): A Catalogue of the Flora of Oklahoma. The Research Foundation, Stillwater. 91 pages. NO DATA YET [3064]

Waterfall, U.T. (1962): Keys to the Flora of Oklahoma. The Research Foundation,
Oklahoma State University, Stillwater. 243 pages. NO DATA YET [20246]

Waterfall, U.T. (1969): Keys to the Flora of Oklahoma. Published by the author, Stillwater, OK. 246 pages. NO DATA YET [830]

Waterfall, U.T.; Wallis, CS (1963): A list of the vascular flora of Oklahoma Ozarks. Proc. Okla. Acad. Sci. 44, 11-22. COMPLETE [109]

White, P.J. (1901): A study of the flora of Oklahoma. M.S. Thesis, University of Oklahoma, Norman. 96 p.

COMPLETE [1234] 
Appendix 2 Geographic data and taxonomic data from Oklahoma floras. The Reference numbers correspond to author references in Appendix 1. Multiple checklists within a reference are indicated by decimals. Note that lists for some areas (especially the state of Oklahoma as a whole) have been compiled multiple times.

\begin{tabular}{|c|c|c|c|c|c|c|c|c|c|c|c|c|c|}
\hline Site name & Year & latitude & longitude & $\begin{array}{l}\text { Min. } \\
\text { Elev. } \\
(\mathrm{m})\end{array}$ & $\begin{array}{l}\text { Max. } \\
\text { Elev. } \\
(\mathrm{m})\end{array}$ & $\begin{array}{c}\text { Area } \\
\text { (hectares) }\end{array}$ & $\begin{array}{c}\# \\
\text { Families }\end{array}$ & $\begin{array}{c}\# \\
\text { Genera }\end{array}$ & $\begin{array}{c}\# \\
\text { spp }\end{array}$ & $\begin{array}{l}\text { \# Tot. } \\
\text { Taxa }\end{array}$ & $\begin{array}{l}\% \text { of } \\
\text { species } \\
\text { alien }\end{array}$ & \multicolumn{2}{|c|}{$\begin{array}{c}\text { Appendix I } \\
\text { Author } \\
\text { Reference }\end{array}$} \\
\hline Great Plains & 1986 & 41.5 & -104.0 & 290 & 1600 & 152226662 & 160 & 851 & 2862 & 3189 & 11.5 & Grea & 536 \\
\hline Mesa de Maya Region & 1953 & 37.3 & -103.7 & 1524 & 2088 & 56175 & 75 & 293 & 577 & 589 & 8.3 & Roge & 2051 \\
\hline Black Mesa Preserve & 1994 & 36.9 & -103.0 & 1456 & 1516 & 36 & 55 & 172 & 243 & 244 & 6.6 & $\mathrm{McPh}$ & 21362 \\
\hline Black Mesa State Park & 2004 & 36.9 & -102.9 & 1298 & 1516 & 312 & 58 & 191 & 300 & 301 & 7.0 & Foll & 21363 \\
\hline Washita Battlefield NHP & 2004 & 35.6 & -99.7 & 588 & 610 & 136 & 62 & 201 & 271 & 271 & 11.4 & Hoag & 21491 \\
\hline Greer County & 1932 & 34.9 & -99.6 & 487 & 669 & 165700 & 65 & 245 & 401 & 401 & 6.7 & Bull & 94 \\
\hline Gypsum Hills and Redbed Plains & 1975 & 34.7 & -99.5 & 366 & 671 & 514892 & 63 & 230 & 354 & 359 & 9.6 & Barb & 90 \\
\hline Altus Air Force Base & 1996 & 34.7 & -99.3 & 408 & 425 & 1036 & 63 & 175 & 232 & 233 & 17.2 & John & 21373 \\
\hline Selman Living Laboratory & 2002 & 36.7 & -99.2 & 511 & 560 & 130 & 60 & 155 & 226 & 226 & 9.7 & Buck & 21259 \\
\hline Selman Living Laboratory & 2003 & 36.7 & -99.2 & 511 & 560 & 130 & 61 & 149 & 229 & 229 & 9.2 & Buck & 21316 \\
\hline Kiowa Co. & 1937 & 34.8 & -99.1 & 399 & 730 & 265475 & 81 & 269 & 497 & 527 & 7.6 & Bald & 89 \\
\hline Gypsum dominated site & 2005 & 36.4 & -98.9 & 457 & 508 & 80 & 61 & 173 & 233 & 233 & 9.4 & Hoag & 21706 \\
\hline Hackberry Flat & 2004 & 34.3 & -98.9 & 349 & 366 & 2770 & 33 & 99 & 121 & 122 & 17.4 & Hoag & 21360.2 \\
\hline three sites in Tillman County & 2004 & 34.4 & -98.9 & 332 & 381 & 3842 & 69 & 241 & 357 & 352 & 13.7 & Hoag & 21360 \\
\hline Suttle Creek & 2004 & 34.2 & -98.9 & 332 & 358 & 161 & 55 & 155 & 182 & 182 & 9.3 & Hoag & 21360.3 \\
\hline Little Sahara State Park & 1980 & 36.5 & -98.9 & 423 & 470 & 146 & 55 & 145 & 181 & 181 & 6.6 & Sher & 107 \\
\hline Frederick Lake & 2004 & 34.5 & -98.9 & 360 & 381 & 911 & 52 & 155 & 185 & 187 & 10.3 & Hoag & 21360.1 \\
\hline Oklahoma & 1952 & 35.2 & -98.8 & 87 & 1516 & 17814538 & 141 & 741 & 2247 & 2542 & 8.9 & Wate & 3064 \\
\hline Oklahoma & 1994 & 35.2 & -98.8 & 87 & 1516 & 17814538 & 172 & 850 & 2549 & 2844 & 14.6 & Tayl & 20006 \\
\hline Territory of Oklahoma & 1900 & 35.3 & -98.8 & 110 & 1516 & 10108770 & 97 & 377 & 724 & 737 & 6.6 & Bogu & 1228 \\
\hline Territory of Oklahoma & 1902 & 35.3 & -98.8 & 111 & 1516 & 10108770 & 103 & 412 & 811 & 812 & 6.4 & Van & 1232 \\
\hline Oklahoma & 1930 & 35.3 & -98.8 & 88 & 1516 & 17781645 & 125 & 661 & 1957 & 1981 & 7.7 & Jeff & 1117 \\
\hline Oklahoma & 1991 & 35.2 & -98.8 & 87 & 1517 & 17944297 & 159 & 846 & 2548 & 2830 & 11.9 & Tayl & 1964 \\
\hline Wichita Mountain Wildlife Refuge & 1977 & 34.8 & -98.7 & 387 & 751 & 23885 & 104 & 359 & 730 & 749 & 5.5 & Buck & 674 \\
\hline Fort Sill & 1990 & 34.7 & -98.5 & 329 & 673 & 38300 & 99 & 344 & 556 & 562 & 11.5 & John & 671 \\
\hline Salt Plain National Wildlife Refuge & 1964 & 36.8 & -98.2 & 343 & 369 & 12955 & 71 & 200 & 293 & 298 & 9.6 & Baal & 3248 \\
\hline
\end{tabular}

Palmer, M.W. 


\begin{tabular}{|c|c|c|c|c|c|c|c|c|c|c|c|c|c|}
\hline Kegelman Auxiliary Field & 1996 & 36.7 & -98.1 & 345 & 370 & 431 & 68 & 187 & 276 & 277 & 9.1 & John & 21371.1 \\
\hline Pottawatomie County & 1933 & 35.1 & -98.0 & 274 & 345 & 212380 & 76 & 228 & 372 & 374 & 10.2 & Bark & 92 \\
\hline Oklahoma & 1901 & 36.0 & -98.0 & 86 & 1516 & 17781904 & 93 & 226 & 419 & 421 & 1.4 & Whit & 1234 \\
\hline Vance Air Force Base & 1996 & 36.3 & -97.9 & 388 & 401 & 740 & 31 & 77 & 94 & 94 & 46.8 & John & 21371 \\
\hline Cleveland County & 1994 & 35.2 & -97.9 & 311 & 386 & 137011 & 160 & 362 & 605 & 605 & 17.5 & Foll & 4852 \\
\hline Frank Tract & 1998 & 36.2 & -97.7 & 229 & 323 & 340 & 72 & 187 & 268 & 268 & 7.5 & Roe & 20001 \\
\hline Oklahoma County & 2001 & 35.6 & -97.4 & 267 & 429 & 186000 & 91 & 308 & 601 & 644 & 12.5 & Hoag & 20010 \\
\hline Deer Creek Archaeological Site & 1980 & 36.7 & -97.4 & 291 & 294 & 12 & 48 & 113 & 147 & 148 & 12.9 & Tyrl & 2056 \\
\hline Arbuckle Mountains & 1908 & 34.4 & -97.1 & 228 & 396 & 55943 & 73 & 162 & 211 & 221 & 5.7 & Gage & 98 \\
\hline Love Valley WMA & 2004 & 33.8 & -97.1 & 197 & 243 & 3134 & 86 & 258 & 368 & 368 & 8.4 & Hoag & 21707 \\
\hline Chickasaw NRA & 2001 & 34.5 & -97.0 & 240 & 352 & 3849 & 105 & 397 & 713 & 717 & 12.2 & Hoag & 20021 \\
\hline Arbuckle Mountains & 1947 & 34.5 & -96.9 & 229 & 415 & 222740 & 96 & 397 & 823 & 867 & 8.4 & Dale & 96 \\
\hline Pennington Creek & 1997 & 34.4 & -96.7 & 251 & 263 & 3 & 64 & 157 & 203 & 203 & 4.9 & Shan & 20003 \\
\hline Pontotoc County & 1958 & 34.7 & -96.7 & 244 & 396 & 185781 & 98 & 380 & 698 & 730 & 1.6 & $\mathrm{McCo}$ & 101 \\
\hline Pontotoc Ridge Preserve & 1998 & 34.4 & -96.6 & 257 & 340 & 1174 & 79 & 261 & 399 & 402 & 7.0 & John & 21372 \\
\hline Keystone WMA & 2003 & 36.1 & -96.5 & 222 & 237 & 4893 & 79 & 254 & 380 & 380 & 15.5 & Hoag & 21364 \\
\hline Tallgrass Prairie Preserve & 1993 & 36.8 & -96.4 & 256 & 352 & 12250 & 78 & 273 & 496 & 496 & 11.5 & Palm & 1975 \\
\hline Tallgrass Prairie Preserve & 1993 & 36.8 & -96.4 & 256 & 352 & 12250 & 81 & 258 & 517 & 517 & 8.9 & The & 4095 \\
\hline $\begin{array}{l}\text { Boehler Seeps and Sandhills } \\
\text { Preserve }\end{array}$ & 1997 & 34.2 & -95.9 & 155 & 175 & 235 & 84 & 225 & 345 & 346 & 4.3 & Clar & 20002 \\
\hline $\begin{array}{l}\text { Oolagah Wildlife Management } \\
\text { Area }\end{array}$ & 2003 & 36.7 & -95.6 & 192 & 258 & 5226 & 95 & 305 & 470 & 470 & 8.3 & Hoag & 21315 \\
\hline Hugo Lake WMA & 2004 & 34.1 & -95.5 & 121 & 154 & 6475 & 113 & 359 & 573 & 573 & 8.9 & Hoag & 21407 \\
\hline Muskogee County & 1938 & 35.5 & -95.4 & 183 & 301 & 213934 & 131 & 424 & 829 & 842 & 8.9 & Litt & 99 \\
\hline Muskogee County & 1929 & 35.6 & -95.4 & 142 & 300 & 219240 & 104 & 423 & 828 & 842 & 9.1 & Litt & 1882 \\
\hline Pushmataha WMA & 2003 & 34.5 & -95.4 & 150 & 400 & 7690 & 96 & 287 & 447 & 447 & 7.2 & Cran & 21287 \\
\hline Camp Gruber & 1994 & 35.7 & -95.1 & 152 & 327 & 19500 & 101 & 347 & 561 & 568 & 8.0 & John & 21370 \\
\hline Sans Bios/Kiamichi & 1969 & 34.8 & -94.9 & 152 & 914 & 277482 & 119 & 457 & 991 & 1067 & 7.9 & Mean & 104 \\
\hline Oklahoma Ozarks & 1963 & 36.1 & -94.8 & 140 & 457 & 875316 & 125 & 515 & 1206 & 1318 & 2.8 & Wate & 109 \\
\hline Red Slough/Grassy Slough WMA & 2004 & 33.8 & -94.8 & 200 & 113 & 2422 & 106 & 269 & 426 & 426 & 6.6 & Hoag & 21479 \\
\hline Red Slough WMA & 2004 & 33.7 & -94.8 & 100 & 104 & 2158 & 106 & 269 & 422 & 422 & 6.6 & Hoag & 21479.1 \\
\hline Grassy Slough WMA & 2004 & 33.8 & -94.8 & 105 & 113 & 264 & 92 & 221 & 318 & 318 & 6.6 & Hoag & 21479.2 \\
\hline McCurtain County Wilderness & 1997 & 34.3 & -94.7 & 183 & 415 & 5701 & 95 & 236 & 359 & 359 & 5.8 & Smit & 20005 \\
\hline Sally Bull Hollow Tract & 2003 & 34.7 & -94.6 & 300 & 500 & 810 & 62 & 145 & 219 & 219 & 8.7 & Haye & 21266 \\
\hline
\end{tabular}

